\title{
How the Emergencies State are Positioning in the New Global Economic Order
}

\author{
Valentin Sava \\ Dunarea de Jos University of Galati, Romania \\ valentin.sava@,ugal.ro \\ Manuela-Violeta Tureatcă \\ Romanian Academy "INCE Kiritescu”, Bucuresti, Romania \\ Daniela Ludmila Manea \\ manealudmiladaniela@gmail.com \\ Dunarea de Jos University of Galati, Romania
}

\begin{abstract}
The article describes emerging economies and their role in the global economy. A definition of the term emerging economy is given and the elements that define this concept at present. The most important emerging economies of today are reviewed, as well as the national indicators that qualify them to be considered as emerging. The article highlights the most important development trends that can be observed in the current period in emerging countries as well as the diversity of factors underlying the analysis of emerging economies. It also highlights the role of each factor in the macroeconomic development of each major emerging state, stating their recent developments and the importance for the development of the global economy. In this respect, it is highlighted the major role of foreign trade stimulated by the low level of costs of exported manufactures products and also by the depreciated national currency compared to the currency of the destination country. The article highlights the characteristic features of the current period and reviews the possibilities for economic and social development of the main emerging countries in the current economic and financial context. It is also underlined the role of the emerging country's macroeconomic growth in raising the country's living standards, which is a tool of national economic policy. At the same time, the importance of national investments in infrastructure, education, internal consumption is highlighted. The current context is of great importance, with emerging countries being forced to develop and implement appropriate balancing and development policies both economically and socially, taking into account the new global economic order.
\end{abstract}

Keywords: emerging, gross domestic product (GDP), Foreign Direct Investment (IDE), Human Development Index (IDH), Reference Rate, Purchasing Power Parity

\section{Emerging economy}

The term emerging economy is not very precise and not accepted by all macroeconomic analysts. In all cases, however, it is considered that an emerging country is a developing country, which has a high growth rate for a longer period, also aiming at improving living conditions for the population, achieving a strong domestic economy both in terms of production and consumption, consolidation in world economic and financial markets, etc.

\subsection{The concept of emerging economy}

The World Bank classifies the world states into four groups according to their Gross National Income per capita (GNI per head), expressed in US dollars at Purchasing Power Parity (PPP), as follows: 
Table 1. Country classification by gross national average income per capita

\begin{tabular}{lc}
\hline Category of States & $\begin{array}{c}\text { Range of GNI per } \\
\text { capita }\end{array}$ \\
\hline $\begin{array}{l}\text { Low-income, less developed countries } \\
\text { Developing States with intermediate income from the lower } \\
\text { tranche }\end{array}$ & $996-3895$ \\
$\begin{array}{l}\text { Developing countries with intermediate income from the upper } \\
\text { tranche }\end{array}$ & $3896-12055$ \\
Developed states with high income & $>12055$ \\
\hline
\end{tabular}
Source: https://datahelpdesk.worldbank.org/knowledgebase/articles/906519

The notion of emerging economy is not standardized, with international institutions and analysts attributing variable meanings, but they all agree with some common criteria.

Thus, emerging countries are classified in the developing country group, with Gross Domestic Product (GDP) per capita and Human Development Index (IDH) lower than in developed countries but with high economic growth rates and an important volume of exports.

The OECD uses three economic and social criteria, namely three macroeconomic indicators to designate and hierarchize emerging economies within world economies:

- the contribution to the growth of the world economy, ie the growth rate of GDP per capita;

- improving the living conditions of the population, measured by increasing IDH;

- the share of the respective country in international trade and financial exchanges.

Other analysts add to these criteria an important and growing demography, considered as a possible factor of progress, because it offers one of the main development resources, respectively the workforce.

In this respect, in recent works analyzing the evolution of the world economy, particular attention is paid to the variation of demography, correlated with the pace of economic development and, implicitly, the contribution of each country to the achievement of world economic growth.

For example, India's GDP growth rate has reached the highest levels in the world $(7.3 \%$ in 2018 and over 7\% prospects in the coming years), along with an upward trend in population - over 1.3 billion people in 2017, accounting for nearly $18 \%$ of the world's population, the second most populous country in the world, after China.

\subsection{What are the most important emerging states and their geological features}

Ranking a country among emerging countries, although based on pre-announced criteria, is not stable over a longer period, both because of the real fluctuations of those economies and as a result of the methodological interpretations that change in function the major transformations of the global conjuncture.

For example, Asian emerging countries that in the 1960s were qualified as Asian tigers because of their high growth rates - Hong Kong, Singapore, South Korea and Taiwan - have de facto entered the developed countries, although they are sometimes qualified as emerging.

At present, several states have the characteristics of emerging countries and their share in the world economy is increasing - from about 30\% at the end of the 20 th century to over $45 \%$ in 2017 (WBG, 2019, pp. 8-22) their number rising to more than 60 in 2019.

International analysts have come to designate / group them according to some rather less relevant characteristics, so groups can be named with the acronyms of the respective countries: BRICS (Brazil, Russia, India, China, South Africa), CIVETS (Colombia, Indonesia, Vietnam, Egypt, Turkey and South Africa), MIST (Mexico, Indonesia, South Korea and Turkey, BRIICSSAMT (Brazil, Russia, India, Indonesia, China, South Africa, Saudi Arabia, Argentina, Mexico and Turkey) 
The list of emerging countries is not, however, complete, because several countries that are part of the European Union, such as Poland, the Czech Republic, Hungary, even our country, Romania, as well as some countries in Africa, as Nigeria are considered in the same categor.

Of all these appeals, some even fanciful, only BRICS has achieved a real association, concretized by summit meetings between the leaders of the component states, as well as by creating financially helpful institutions such as the Development Bank in 2014, - an alternative to the International Monetary Fund and the World Bank to finance investment policies from member countries but without restricting economic development conditions - and Fund, as a common foreign exchange facility to enable them to hedge risks in the international financial market.

\section{The Economic Characteristics of Emerging States}

\subsection{Consolidated Development Trends of Major Emerging States}

Analyzing the specific features of countries whose macroeconomic development as well as geopolitical power is growing significantly in the world, is highlighted several criteria that can characterize so-called emerging countries:

- sustained growth of economic growth - expressed by the indicator GDP per capita on PPP, measured in an international currency, generally USD.

It is considered that a country's economy is emerging if there is a positive evolution of this indicator for a relatively long period, even if there are years of stagnation or even recession due to internal or external causes.

For example, Russia recorded negative GDP growth rates in 2015 and 2016, mainly due to the global oil price depression, but through an adequate economic policy managed to surpass this period, the forecast for 2019 and the next, regarding the Russian economy beeing having sustained growth.

Thus, emerging countries with a significant weight in the global economy recorded in the early years post-crisis - the financial crisis triggered since 2007 by the mortgage market and the toxic financial titles in the US, generating an economic crisis that has spread across the globe significant economic development deterioration, but the economic and social policies implemented by public authorities in these countries have taken account of the changes in the economy, aiming, first, at restoring the financial balance, followed by the resumption of economic growth.

In this regard, economic policy measures, including financial, have favored the development of high-tech production, the intensification of goods and services exchanges, and the current increase in incomes and, implicitly, in domestic consumption as a major factor of macroeconomic stimulation;

- The large and growing volume of foreign trade. Export receipts allow the state to increase its foreign exchange reserves, thus able to finance both imports of goods and services, as well as the acquisition of high technical and know-how essential to the country's position between the countries aspiring to the developed country status;

- Foreign Direct Investment (IDE) attracted in economic sectors with comparative advantages, such as:

- Existence of important natural resources (such as Russia, Saudi Arabia, South Africa);

- Well-qualified and very active workforce (eg China, Tayland, Singapore);

- Important internal consumer market (eg China, Russia).

Foreign attracted capital funds medium and long-term investments with a high degree of technology that contribute to the achievement of high added value;

- Establishment and diversification of large-scale companies with branches located in different parts of the globe.

Through these multinationals, the developing country is using its capital - which is generally private - to fund large-scale projects in other states that have a comparative advantage in their economic, primarily commercial, relationships. An important example of this is China's 
multinationals investing in several African states, which have natural resources - minerals, hydrocarbons, and so on. - important, to be exploited and exported, in part, to China. Also, private or public capital in an emerging economy can be found in the capital of multinationals specializing in the production of top goods, ie recognized brands in developed countries - for example, automotive companies: the Swedish company Volvo Automobile acquired by the Chinese company Geely Auto, British societies Jaguar and Land Rover, owned by Ford, were acquired by Indian giant Tata, etc.

- a large population where active people, especially young people, have a significant share and provide the national economy with one of the main development factors, namely the human resource. In emerging countries, this factor is of major importance and, in this sense, education and vocational training policies develop carefully monitored and well funded programs, in line with macroeconomic and social development strategies. Moreover, a large population with relatively high average incomes is an important and attractive internal market for the country, including for foreign producers. They are interested both in directing their exports and in locating their subsidiaries / branches in the emerging countries, with the most relevant reasons being the increase in domestic demand and the low cost of labor. At the same time, it should be underlined that only a large number of inhabitants in a country do not provide it with the status of emerging economy if the level of economic development - measured by the GDP per capita indicator, expressed in international currency at the purchasing power parity, does not rise over the world average. hus, only in the last few years, many countries with a large population, such as some African countries, like Nigeria (190.9 million in 2019, GDP per capita 2412 USD in 2017) or Ethiopia (105 million in 2019, GDP per capita 875 USD in 2019) are included in the list of new emerging countries, with positive growth rates, combined with a rise in average personal income. Nigeria is the largest economy and the great oil exporter in Africa, but just this natural wealth has made it vulnerable, as about $80 \%$ of its revenues came from hydrocarbon exports, and the fall in world prices has greatly contributed Nigeria entering into recession in early 2015 .

The resumption of economic growth has taken place in the context of the implementation of reforms that diminish the dependence of natural resource performance and at the same time increase the role of demography as a factor stimulating the achievement of added value in the domestic economy.

Ethiopia has a contradictory development: confronted with a public debt close to the risk threshold - considered in the European Union's view, 60\% of GDP - has implemented policies to recover public finances.

In recent years, Ethiopia has achieved the highest levels of economic growth $(10.7 \%$ in 2016 , $7.7 \%$ in 2017 and $8.5 \%$ in 2018, with the IMF forecast for over 7\% annually), while at the same time managing to diminish public debt at $61 \%$ of GDP in 2017 to $57.5 \%$ in 2018 and with a downward trend, according to IMF Country Report No. 18/354, December 2018). Similarly, a state with high GDP per capita but with a low population density and low demographic density can not be considered as an emerging state. In this regard, it can be mentioned Saudi Arabia, which has an average GDP per capita level (21096,44 USD in 2017, lower than in previous years or thereafter), but which has a population much lower than countries qualifying as emerging (32.55 million inhabitants). Romania is also quoted in some recent papers as a new emerging economy (eg GlobalOutlook 2019, Markets, Investment \& Structuring, Indosuez Wealth Management), due to the growth rates recorded in recent years after the economic crisis $(7 \%$ in 2017, 4.5\% projected for 2018 and 5.5\% predicted for 2019) and the average per capita GDP (10786 USB in 2017), although the population of only 19.58 million in 2018 does not qualify it as an emerging country.

\subsection{The main factors that influence the macroeconomic development of emerging countries}

In one country, the main factors influencing economic development and improving the quality of life are, according to the most synthetic equilibrium macroeconomic equilibrium: 
- internal consumption, directly influenced by population incomes and demographic characteristics;

- public financial policies, namely taxesl and fiscal fees, budgetary expenditures, monetary and public debt policies;

- investing, both in the public sector, and stimulating them in the private sector;

- foreign trade, which involves the accumulation of international financial assets and the degree of exposure of the national economy to foreign affairs.

The number of emerging countries is steadily rising and they are virtually on all continents of the world:

- In Asia there are the most: China, India, Malaysia, Vietnam and so on.

- in North, Central and South America: Mexico, Brazil, Chile, etc.

- in Europe: Russia, Poland, Hungary, Turkey on two continents, etc .;

- in Africa: South Africa, recently Nigeria, Ethiopia and others

For a country to be qualified in the eyes of international economic or financial institutions: the International Monetary Fund (IMF), the World Bank BM), the World Trade Organization (WTO), the Organization for Economic Co-operation and Economic Development (OECD) as an emerging economy has to present some qualitative and qualitative characteristics, which, according to the macroeconomic analysts' assessment, allow, after a number of years of economic and social progress, to be in the category of developed countries. Thus, the quantitative levels of the indicators describing an emerging economy are:

- a large volume of manufactured goods and services exported, which provides the state with a strong position on the international market for goods and services. In this regard, China is the world's largest exporter of goods, India as the most important exporter of IT services, etc.

External commodity trade (\% of global volume)

\begin{tabular}{|c|c|c|c|c|c|c|c|c|c|c|c|c|c|c|}
\hline & \multicolumn{14}{|c|}{ 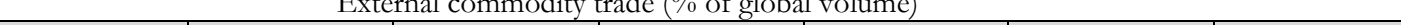 } \\
\hline & \multicolumn{2}{|c|}{2007} & \multicolumn{2}{|c|}{2012} & \multicolumn{2}{|c|}{2013} & \multicolumn{2}{|c|}{2014} & \multicolumn{2}{|c|}{2015} & \multicolumn{2}{|c|}{2016} & \multicolumn{2}{|c|}{2017} \\
\hline & Imp & Exp & Imp & Exp & Imp & Exp & Imp & Exp & Imp & Exp & Imp & Exp & Imp & Exp \\
\hline EU28 & 19.2 & 17 & 15.7 & 15.1 & 15.1 & 15.8 & 15.1 & 15.5 & 14.7 & 15.6 & 15 & 15.9 & 15.1 & 15.8 \\
\hline USA & 19.4 & 11.7 & 15.9 & 10.8 & 15.7 & 10.8 & 16.2 & 11.1 & 17.7 & 11.8 & 17.9 & 12 & 17.3 & 11.5 \\
\hline China & 9.2 & 12.3 & 12.4 & 14.3 & 13.1 & 15.1 & 13.2 & 16 & 12.9 & 17.8 & 12.6 & 17.3 & 13.3 & 16.8 \\
\hline Japan & 6 & 7.2 & 6 & 5.6 & 5.6 & 4.9 & 5.5 & 4.7 & 4.8 & 4.9 & 4.8 & 5.3 & 4.8 & 5.2 \\
\hline Russia & 1.9 & 3.5 & 2.2 & 3.7 & 2.1 & 3.6 & 1.9 & 3.4 & 1.4 & 2.7 & 1.4 & 2.4 & 1.6 & 2.7 \\
\hline India & 2.1 & 1.5 & 3.3 & 2 & 3.1 & 2.3 & 3.1 & 2.2 & 3 & 2.1 & 2.8 & 2.1 & 3.2 & 2.2 \\
\hline Brazil & 1.2 & 1.6 & 1.5 & 1.7 & 1.6 & 1.7 & 1.5 & 1.5 & 1.3 & 1.5 & 1.1 & 1.5 & 1.1 & 1.6 \\
\hline
\end{tabular}

Source: https://ec.europa.eu/eurostat/tgm/tet00018; author's work

As can be seen from the table above, the financial crisis in the US in 2007 had a major impact on global economic transactions as well as on commodity trade of developed countries such as the US, Japan and the European Union, considered in its ensemble. The emerging countries, mainly the high-growth ones like BRIC (Brazil, Riusia, India, China), continued to be major players in the trade market, consolidating their international economic position;

- An economic growth rate, measured by the real GDP growth rate, above the world average. Even if there are relatively large fluctuations of this indicator, a sum of the other characteristics still keeps it between emerging countries. In such a situation, it was recently Russia, considered one of the most important emerging economies, which has experienced a significant reduction in GDP due to the global oil price depression and trade sanctions imposed by some developed countries, such as The United States and the European Union as a result of the Syrian crisis.

- the share of the emerging economy in the economic world is important, above 1\%. From the table below, it is noted that the emerging countries belonging to the BRIC group meet this 
criterion and China, the fastest growing state in the last twenty years, has a share that exceeds the share of the strongest state in the world, today, USA.

\begin{tabular}{lrrrr}
\multicolumn{5}{c}{ The share of national GDP in world GDP } \\
\cline { 2 - 5 } & 2017 & 2018 & $2019 \mathrm{f}$ & $2020 \mathrm{f}$ \\
\hline Total & 100 & 100 & 100 & 100 \\
\hline US & 15.20 & 15.38 & 15.00 & 15.33 \\
Brazil & 2.38 & 2.78 & 2.50 & 2.50 \\
Russia & 3.33 & 3.16 & 2.94 & 3.33 \\
India & 7.71 & 7.67 & 7.67 & 7.78 \\
China & 18.68 & 18.75 & 18.71 & 18.67 \\
\hline
\end{tabular}

Sources:WBG 2019; author's work

The presented characteristics are quantitative and can be documented by the macroeconomic indicators that we find in international statistics, but there are also a number of qualitative characteristics describing the status of emerging economy, the most important ones referring to:

- the proper functioning of public institutions, which are those that implement public policies, while ensuring the protection of citizens' rights and maintaining an adequate level of quality of life.

The Human Development Index (HDI) is, as defined in United Nations statistics, an index calculated for the national level with the help of several variables that take into account the personal per capita income as well as the living conditions, the level of health and education. The table below shows that the BRICS emerging countries are on different positions in terms of quality of life, India being the last one, because of the average gross per capita income. It should be remembered that although India has the highest growth rate in recent years, the population of the Asian sub-continent is over 1.3 billion inhabitants, which is an advantage for labor supply, but in terms of value distribution added among the members of society, this is a major challenge for public authorities.

Romania, which does not be qualified as an emerging economy - although there are currently analysts who place it among the new emerging countries - occupies, according to HDI, the 52nd place among the world's states, being placed among the countries of very high human development.

Table 1. Human Development Index and its components in 2017

\begin{tabular}{c|l|c|c|c}
\hline \multirow{2}{*}{$\begin{array}{c}\text { HDI } \\
\text { rank }\end{array}$} & \multicolumn{1}{|c|}{$\begin{array}{c}\text { Human } \\
\text { Country } \\
\text { Index (HDI) }\end{array}$} & $\begin{array}{c}\text { Life expectancy } \\
\text { at birth }\end{array}$ & $\begin{array}{c}\text { Gross national } \\
\text { income (GNI) per } \\
\text { capita }\end{array}$ \\
\cline { 3 - 5 } 13 & Value & (years) & $(2011$ PPP \$) \\
49 & Russian Federation & 0.924 & 79.5 & 54,941 \\
52 & Romania & 0.816 & 71.2 & 24,233 \\
79 & Brazil & 0.759 & 75.6 & 22,646 \\
86 & China & 0.752 & 75.7 & 13,755 \\
113 & South Africa & 0.699 & 76.4 & 15,270 \\
130 & India & 0.640 & 63.4 & 11,923 \\
\hline \multicolumn{2}{l|}{ Sources: http://hdr.undp.org/en/composite/HDI } \\
\multicolumn{3}{|c}{}
\end{tabular}

- the degree of attractiveness of the respective economy for direct investment (IDE) is a signal that it is perceived in the world heritage market as having comparative advantages, with 
predictions of profitability increasing. Among the factors that are analyzed for this purpose are:

- the existence of natural resources;

- a large and well-trained workforce;

- low cost of human resources

- the quality of infrastructure in the key areas of economic and social activity: energy, transport, telecommunications, health, social, education, environmental protection etc .;

- innovation and technological advance;

- the quality of governance, materialized by achieving the objectives of the structural reforms at the projected parameters;

- democracy, respect for and guaranteeing human rights, political stability, etc.

The progress of the emerging countries in the world economy was based, initially - in the 1980s on the export stimulation, mainly of natural resources and / or manufactured goods, based either on the underground wealth or the low labor costs. Exporting countries have accumulated a considerable amount of international financial assets, which allowed them to support large-scale internal development programs with increasing employment of available labor.

The most conclusive example is, obviously, China. Although with a long-term slowdown in population growth, China currently has about 1.4 billion inhabitants, and thanks to its education and training programs, it provides the national industry with a major support for enlargement, both in volume and in scale from a technological point of view, the $\mathrm{R} \& \mathrm{D}$ sector is also a privileged area of public financial support.

In the current political and economic context, when several developed countries, primarily the United States, are trying differently to limit the volume of imports, one of the most effective instruments for boosting economic growth is domestic consumption.

\section{Place of emerging countries in the world economy}

Emerging states occupy a growing position in the global economy, relying on the comparative advantages they have: well-qualified but less paid workforce, rich natural resources, production of goods and / or services at lower cost than in developed countries. These countries have large export receipts, their current trade balance being surplus, with many capital flows coming in due to the location of multinational subsidiaries / branches.

Economic growth is favorable to the gradual increase in the available incomes of the population, which means to increase purchasing power, with beneficial effects on domestic consumption, this macroeconomic indicator being an important factor for growth.

However, the living standards in emerging countries remain much lower than in developed ones, with development strategies adopted by public authorities consistently aiming to raise this level by allocating important public funds for this purpose.

The pace of development of emerging countries varies from country to country, but overall it is much higher than developed economies, with the gap between them decreasing substantially, so it is estimated that in 2030 the newly created value in emerging countries will exceed $60 \%$ of the total newly created value globally, which will greatly change the world economic balance.

In this respect, macroeconomic analysts - both from specialized institutes and from international institutions: the International Monetary Fund, the World Bank, the Organization for Economic Co-operation and Development (OECD), and large-scale national insti tutions such as the CIA The United States - estimates that major emerging countries: China, India, Brazil, Russia will become centers of power not only economic but also political, comparable to the big developed economies: the US, the European Union, Japan.

\subsection{Characteristics of the current economic situation}

After the financial crisis of 2007-2008, the US economy has experienced the most uninterrupted period of uninterrupted economic growth in its modern history, and this growth has been increasing over the past two years (real GDP growth of 2.5\% in 2017, $2,8 \%$ in 2018, the 
forecast for 2019 being 2.6\%, according to the OECD Economic Survey 2018) due to the fiscal policy implemented by Republican President Trump's administration. Among the most important measures are:

- lowering the corporate tax rate for all enterprises from $35 \%$ to $20 \%$, while eliminating tax deductions, but also tax credits;

- the personal income tax cuts were reduced from 7 to 4 , with the respective quotas being: $12 \%, 25 \%, 35 \%$ and $39.6 \%$, which leads to an average decrease in the pressure on income tax ;

- exemption from inheritance tax up to USD 11 million per person $\square$ decreased from 39.6\% to $25 \%$ );

- the elimination of the minimum tax imposed on all taxpayers who would have been subject to a low tax.

As a consequence, the US monetary policy has relaxed, the dollar has appreciated, the price of hydrocarbons has started to rise.

With this positive development, the Trump administration said it wanted to implement a protectionist policy towards several trading partners because of the current account deficit and declining industrial output in several sectors of the national economy.

This type of policy has affected emerging economies - their main growth factor being exports of manufactured goods and / or services - especially China's economy, the world's largest exporter at present

For more than a decade, the United States and China are the economies that drive global economic growth. Following the financial crisis triggered by the US mortgage market since 2007, the US has undergone a long sustained growth cycle - followed by expansion - and in the coming years it is expected that the stimulus effect created by the Keynes interventionist policy flatten gradually.

This development will be exacerbated by the public spending policy launched by the US administration, which aims at reducing public debt and funding social protection programs for disadvantaged people.

In this context, the Federal Reserve System (Fed) benchmark rate will increase, yielding interest rates and, consequently, appreciating the national currency, the US dollar, which is the most international convertible currency.

This development adversely affects the economies of the partner countries the US, but especially emerging countries from the commercially and financially point of view.

\subsection{Characteristics of economic evolution of emerging states in the current situation}

In the competition for supremacy in the global economic market, the instruments used by the national authorities are of various types: economic - production, investments; commercial - real flows and their counterpart; financial-monetary - fiscal, monetary, foreign exchange policies.

The commercial war that the US administration is currently promoting concerns primarily the protectionism applied to the US economy by imposing customs duties that can be considered as retaliation for commodities and products from certain countries such as China, Turkey or geographical areas, as is the European Union, which could, in the intention of those who impose it, produce a reduction in the US current account deficit vis-à-vis those countries.

The export of emerging countries have boosted their exports in various ways, one of the instruments being the depreciation of the national currency in relation to the US dollar.

By imposing increased customs duties, exports to the US are discouraged, and an extra depreciation / devaluation of the national currency in emerging countries risks putting them into a currency crisis.

The appreciation of the dollar, which may have a beneficial effect on US exports to the US, will, however, have an adverse effect on dollar-denominated indebted countries, with the public debt burden imbalanced in a significant way by economies - especially developing and emerging 
economies - an effective public debt / GDP ratio, and a higher public debt growth rate than the GDP growth rate.

Recent developments and development prospects for emerging countries do not present a common denominator, the characteristics of which are very different: macroeconomic development level, geographic location and both economic and geo-political relations, history and culture, etc.

Even between states that have joined in a group that seeks to act solitatively in response to the challenges that have arisen in the global conjunctural changes, there are significant differences. The most relevant example nowadays is the countries that form the group of BRICS emerging countries.

The economy of Brazil has experienced serious fluctuations, despite - and perhaps even because of - the important natural resources at its disposal, but the macroeconomic situation is now showing real improvement, employment and rising real wages allowing domestic consumption to grow, the use of this macroeconomic tool in the growth strategy.

Russia has recently faced with destabilizing economic sanctions, mainly from the United States, as well as with a negative conjuncture on the world oil market, which strongly affected its macroeconomic balance, as the Russian economy is still very dependent on oil exports .

Consequently, policies implemented by public authorities have acted to consolidate public finances and their use to support intervention programs aimed at stimulating domestic consumption covered by domestic production, including agriculture, food industry and light industry, while at the same time increasing public spending in key areas such as education, health, infrastructure, support for SMEs, etc.

India is one of the emerging countries with one of the highest economic growth forecasts in the world. Beginning in 1990, India's economic growth is based on a number of industrial sectors with a significant share in international trade: steel, automobile, being the largest exporter of computer services, generics and services to productive entities.

Thus, according to the Report on investment in the world (2018), although with a level of foreign direct investment much lower than that of China (13.4\% in 2016, 16.8\% in 2017 in total entries Foreign Direct Investment (IDE), Continental China plus Hong Kong), India remains one of the attractions for foreign capital (2.4\% in 2016, $2.8 \%$ in 2017).

China, the world's largest emerging economy, will now feel the aftermath of the US-led commercial war, as well as the monetary consequences of the US fiscal-budgetary policy on the global economy.

However, macroeconomic analysts estimate that the impact on the Chinese economy will not be very strong, and although in the past two years China has seen a slowdown in growth $(6.9 \%$ in $2017,6.6 \%$ in 2018, and $6,2 \%$ in 2019 forecast, according to www.statista.com), occupying the first or second position in the global market, which will not be shaken in the next few years.

We must remember that China's economic recovery began in the 1980s, after the death of Communist leader Mao Zedong. Although a command economy remained, China gradually adopted the features of a market economy, with economic growth relying mainly on manufacturing output - the cost of labor being very low - investment and infrastructure development.

At present, the Chinese public authorities consider and implement a strategic reorientation, taking into account the new internal economic and social conjuncture. Thus, the workforce, with a much improved level of education due to education and training programs, is paid much better, constituting a significant middle class.

On the other hand, the authorities' attention to public research and development, both financially and patrimonically, has raised the degree of technology of the Chinese economy to international standards, which means that Chinese products - made by purely Chinese companies or subsidiaries / branches of multinationals located in China - rivals the international market with any similar products but at lower prices. 
In this context, China's economic and social development strategy now has a pillar of increasing domestic spending, both for the consumption of the population and for the development of private entrepreneurship, rather than for public investment.

Macroeconomic analysts consider as emerging economies a number of countries in all continents, their characteristics being very diverse.

For example, Turkey, which has a unique world position on two continents and a single geostrategic position, is currently facing a difficult situation due to controversial relations with the United States, and the Turkish economy will bear the effects of macroeconomic reforms in the coming years which are aimed at reducing the inflation and the current account deficit, while stimulating investments.

Although they are not given the same attitude as the BRICS group, other emerging economies produce an important signal on the global market. For example, among East European countries that have integrated the European Union, but who are trying to raise their own strength to the developed state level, is Hungary with a sustained level of election - an annual average of 4.5\% after the financial crisis - and who are looking for their own development path.

Many other countries in other parts of the world such as Mexico are trying to restore macroeconomic equilibrium through trade agreements, mainly with the United States, to impose budgetary discipline and ensure the independence of the national bank; Israel, where domestic demand is high, and exports of goods and services are one of the main engines of development; Argentina, which will be able to overcome the recession through its current account surplus;

Ukraine, in a very complicated geopolitical position, relies on the IMF's intervention, but has to face the numerous repayment obligations in foreign currencies and, at the same time, will have to implement far-reaching structural policies for the state to remain solvent and accepted by national society; South Korea is a solid economy, one of the "Asian tigers" of the 1970s, which, despite the US-China trade war, must not change its investment and commercial priorities; Egypt is one of the most exciting emerging economies with a resource of skilled labor, a prudent level of funding, both publicly and by the banking sector.

\section{References}

Francis Généreux, La montée du protectionnisme et les perspectives d'une guerre commerciale mondiale (2018), Point de vue économique, Desjardins, Études économiques, https: / / wnw.desjardins.com

Scénario macro-économique 2019-2020. De nombreux virages à bien négocier (2018), bttps:/ / wnw.creditagricole.com

World Bank Group (WBG), Global Economic Prospects 16 | January 2019, bttp:/ / www.worldbank.org/en/publication/global-economic-prospects

World Investment Report 2018, UNCTAD/WIR/2018, worldinvestmentreport.org

bttp:// bdr.undp.org/en/ composite/HDI

bttps:/ / www.worldbank.org

https:/ / ec.europa.eu/ eurostat/tgm/tet00018

https:/ / datahelpdesk.worldbank.org/knowledgebase

www.statista.com 